\title{
Effects of season and herd milk volume on somatic cell counts of Florida dairy farms
}

\author{
F. C. Ferreira* ${ }^{*}$ and A. De Vries ${ }^{* 1}$ \\ *Department of Animal Sciences, University of Florida, Gainesville 32611 \\ †EMBRAPA, Gado de Leite, Juiz de Fora, Brazil 36038-330
}

\begin{abstract}
Dairy farms in Florida produce less milk and milk with higher somatic cell counts (SCC) in the hot and humid summer. This has consequences for the interpretation of average milk quality. The objectives were to describe the associations of bulk tank SCC (BTSCC) with time of the year and the milk volume per farm. Monthly BTSCC and milk volume records from $84 \%$ (in 2012; $\mathrm{n}=1,308$ ) and $77 \%$ (in 2013; $\mathrm{n}=1,200$ ) of the 130 dairy farms in Florida were used. Data were analyzed separately per year. We calculated arithmetic averages of the BTSCC for each farm (ASCCf), each month (ASCCm), and each year (ASCCy). We used the milk volume to calculate a milk-weighted average for each farm (WSCCf), each month (WSCCm), and each year (WSCCy). Period 1 (P1) was defined as February, March, and April, and period 2 (P2) was defined as August, September, and October. These periods generally had the lowest and highest BTSCC throughout the year, respectively. Seasonality was expressed by the P2/P1 ratios of BTSCC and milk volume in both periods. In 2012 and 2013, 72 and $74 \%$ of the monthly milk volume observations were $<400,000$ cells $/ \mathrm{mL}$. A clear seasonal pattern with lower milk volume and higher ASCCm during P2 was observed for most farms. The averages of the $\mathrm{P} 2 / \mathrm{P} 1$ ratio of milk volume were 0.68 and 0.74 in 2012 and 2013. The averages of the $\mathrm{P} 2 / \mathrm{P} 1$ ratio of SCC were 1.30 and 1.65 for 2012 and 2013, respectively. The WSCCy was 297,000 cells/mL in 2012 and 274,000 cells $/ \mathrm{mL}$ in 2013 . These values were 13 and $16 \%$ lower than the ASCCy in the respective years. In 2012, $82 \%$ of the farms shipped milk with a lower WSCCf than their ASCCf. In 2013, 97\% of the farms shipped milk with a lower WSCCf than their ASCCf. The difference between a farm's WSCCf and its ASCCf tended to be greater in more-seasonal farms for BTSCC and milk volume. The WSCCm was lower than the ASCCm in every calendar month in both years. Collectively, these
\end{abstract}

Received August 1, 2014.

Accepted February 6, 2015.

${ }^{1}$ Corresponding author: devries@ufl.edu results show that the SCC of pooled milk from Florida was substantially lower than the arithmetic averages of monthly BTSCC values. Therefore, it should be made clear if the SCC is weighted by milk volume when "average" SCC results are reported. Programs to improve milk quality in Florida might be focused on conditions during August, September, and October because the BTSCC is then markedly increased on many farms.

Key words: Florida, seasonality, milk volume, somatic cell count

\section{INTRODUCTION}

Elevated SCC are an indication of intramammary infection. Elevated SCC adversely affect the quality of fluid milk (Ma et al., 2000) and reduce shelf life (Barbano et al., 2006). Increased SCC are associated with lower milk production by cows (Hand et al., 2012). Increasingly, milk prices are dependent on SCC. The SCC is also the main milk quality measure that is regulated throughout the world (van Schaik et al., 2002; Schukken et al., 2003). In the United States, the standard maximum SCC in grade A milk is 750,000 cells/mL (FDA, 2009), but states such as California and Idaho and also individual milk processors have reduced the acceptable SCC limit (USDA-APHIS, 2013). A maximum SCC of 400,000 cells/mL has progressively been adopted as the international export standard in many countries (More, 2009; USDA-AMS, 2011). The maximum acceptable SCC level in the European Union is based on a 3-mo rolling geometric average (More et al., 2013). In the United States, a maximum limit of 400,000 cells/mL has frequently been proposed by several dairy organizations (Norman et al., 2011). Hence, dairy farmers have several incentives to produce milk with lower SCC.

Programs to improve milk quality may depend on how the average SCC is calculated and whether milk volume is considered (Allore et al., 1997). Pighetti et al. (2014) reported an arithmetic average SCC of 388,000 cells/mL for Florida farms in 2012 using bulk tank SCC (BTSCC) data from all 130 farms inspected by the Florida Department of Agriculture and Consumer Services. This average SCC was independent of how much 
milk was produced by each farm and in which season. The DHIA reported SCC averages of 267,000 cells $/ \mathrm{mL}$ (2012; 31 farms) and 229,000 cells/mL (2013; 23 farms) for the Florida dairy farms that participated in DHIA mastitis screening (Norman and Walton, 2014). Federal Milk Marketing Order 6 (FO6), which comprises geographically the state of Florida except the most western counties where few dairy farms are located, reported average SCC of 293,000 cells/mL and 264,000 cells/mL in 2012 and 2013, respectively (Atlanta Market Administrator, 2014). These annual FO6 SCC values are the arithmetic averages of the 12 monthly SCC values where each month's SCC is based on producer milk weight and payroll data provided by handlers (Atlanta Market Administrator, 2014).

In many regions, SCC has a seasonal pattern with increases during the summer and decreases during the winter months (Schukken et al., 1992; Olde Riekerink et al., 2007; Archer et al., 2013). Summer heat stress, more cows in later stages of lactation (Green et al., 2006), changes in diets, and mixing of groups (Harmon, 1994) may all be contributing factors. In the United States, the highest percentages of DHIA test-day SCC exceeding the official thresholds are in the summer months (Norman et al., 2013; Norman and Walton, 2014). In the FO6 data, the highest SCC were observed in August (332,000 and 324,000 cells/mL for 2012 and 2013, respectively; Atlanta Market Administrator, 2014). The lowest FO6 SCC value was observed in December 2012 (258,000 cells/mL; 68\% of August) and March 2013 (211,000 cells/mL; 65\% of August), respectively.

In Florida, milk production also has a seasonal pattern where typically the most milk is produced in March and the least amount of milk is produced in September (USDA-AMS, 2013; USDA-NASS, 2014). Compared with March, the volume of milk produced in September ranged from 69 to $72 \%$ for 2010 to 2013 . The seasonal pattern in milk volume in Florida is primarily caused by differences in milk per cow because the number of cows throughout the year is fairly constant (USDANASS, 2014). Cows produce less milk during the summer because in Florida most of the calvings occur in the fall and winter (DeLorenzo et al., 1992; De Vries et al., 2005), which results in more cows in the lower producing stage of their lactation in the summer. In addition, summer heat stress reduces milk production directly (St-Pierre et al., 2003; West, 2003) and affects most herds in Florida.

Average SCC and the seasonality of SCC and milk production in Florida have recently been documented by several authors (Norman et al., 2013; Norman and Walton, 2014; Pighetti et al., 2014). The relationships between farm milk volume, seasonality of milk pro- duction, and BTSCC have not been documented for Florida, however. The pooled SCC of all milk produced in Florida during a year is likely lower than the arithmetic average of monthly BTSCC values reported for each farm. The reputation of the state's milk quality may depend on how the state average SCC is calculated and presented.

The objectives of the present study were to describe the association of BTSCC in Florida milk with time of the year and the volume of milk shipped per farm. One hypothesis was that dairy farms that shipped more milk had a lower BTSCC. A second hypothesis was that dairy farms that had a greater seasonality in milk volume also had a greater seasonality in BTSCC. Consequently, more-seasonal farms in their BTSCC and milk volume are likely to have greater differences between the arithmetic average BTSCC and the pooled BTSCC weighted by milk volume.

\section{MATERIALS AND METHODS}

\section{Data Set}

Monthly total volumes of milk shipped and monthly average BTSCC were provided for 122 and 106 of the 130 Florida dairy farms in 2012 and 2013 by the 2 largest milk buyers in Florida. Both milk buyers were cooperatives. Complete records for both BTSCC and milk volume for 12 consecutive months were available for 109 (84\%) and 100 (77\%) farms in 2012 and 2013, respectively. The remaining farms had between 1 and 11 records per year because these farms either went out of business or changed milk buyers during the year. We used only data from the farms with all 12 observations (both milk volume and average BTSCC), for a total of 2,508 complete records, to avoid potential biases.

The monthly BTSCC value for a farm was the arithmetic average of all SCC measurements taken by the milk buyers in the milk shipments in that month. In most cases, each milk shipment was a full truck with milk from a single farm. In other cases, a truck was only partially filled and the BTSCC measurements were made on variable amounts of milk shipped. The monthly BTSCC value for a farm was therefore not weighted by the volumes of milk that were shipped in that month. The BTSCC values that we received were presented in thousands cells per milliliter. Data on individual milk shipments were not available.

\section{BTSCC Categories}

Five different BTSCC thresholds were set to describe the changes in BTSCC frequencies throughout the year. The first limit of 200,000 cells/mL is sometimes 
used to mark a cow as having mastitis (Sordillo et al., 1997). The second limit of 300,000 cells $/ \mathrm{mL}$ is near the state average. The third limit of 400,000 cells $/ \mathrm{mL}$ is the maximum acceptable SCC level by many countries and also processors within the United States (More, 2009; Norman et al., 2011). Because only $1 \%$ of the monthly BTSCC observations were above the limit of 750,000 cells $/ \mathrm{mL}$ in this study, we decided to set the fourth limit to $600,000 \mathrm{cell} / \mathrm{mL}$.

\section{Arithmetic Average SCC}

We calculated the arithmetic average SCC for each calendar month across all farms (ASCCm), the arithmetic average SCC for each farm across all 12 calendar months (ASCCf), and the arithmetic average SCC of all observations in a year (ASCCy). These arithmetic averages therefore do not account for milk volume.

\section{Weighted Average SCC}

Milk-weighted SCC were calculated for each calendar month (WSCCm) across all farms as follows:

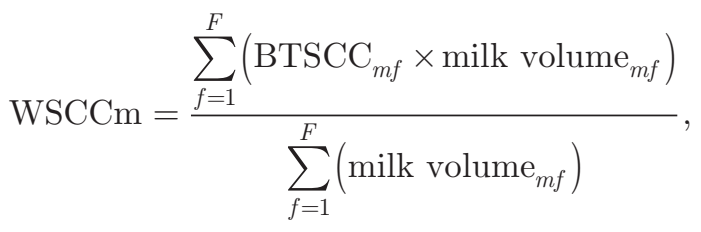

where milk volume is the monthly volume of milk shipped for a farm, $m$ is month, $f$ is farm, and $F$ is the number of farms with data available in a year. The WSCCm is an estimate of the pooled SCC in all Florida milk shipped in that calendar month $(\mathrm{n}=12$ per year). For each year, we calculated the 12 monthly differences (DIFm) as WSCCm minus ASCCm. The DIFm represents the difference in the SCC of all pooled milk shipped and the arithmetic average of the 12 BTSCC observations.

Weighted SCC were also calculated for each farm (WSCCf) across all calendar months as follows:

$$
\mathrm{WSCCf}=\frac{\sum_{m=1}^{12}\left(\text { BTSCC }_{m f} \times \text { milk volume }_{m f}\right)}{\sum_{m=1}^{12}\left(\text { milk volume }_{m f}\right)},
$$

where milk volume, $f$, and $m$ are as previously defined. The WSCCf is an estimate of the pooled SCC of all milk shipped by a farm in a year. The difference (DIFf) was calculated as WSCCf minus ASCCf and represented the difference in the pooled SCC of all milk shipped by a farm and the farm's arithmetic average of the 12 BTSCC observations.

Finally, an overall weighted SCC (WSCCy) was calculated per year as follows:

$$
\mathrm{WSCCy}=\frac{\sum_{f m=1}^{F M}\left(\mathrm{BTSCC}_{m f} \times \text { milk volume }_{m f}\right)}{\sum_{f m=1}^{F M}\left(\text { milk volume }_{m f}\right)},
$$

where milk volume, $f$, and $m$ are as previously defined, and $F M$ is the number of farm-month observations in that year $(F M=1,308$ for 2012 and $F M=1,200$ for 2013).

\section{Period 2/Period 1 Ratios to Describe Seasonality}

To describe seasonality in milk volume and in BTSCC, we choose the 3 calendar months with generally the highest and lowest BTSCC across the data set. The 3 mo with the highest values were August, September, and October, which we defined as period 2 (P2). Similarly, we defined period 1 (P1) as February, March, and April. Because P2 (92 d) is longer than P1 (90 d in 2012, $89 \mathrm{~d}$ in 2013), the milk volume in P1 was multiplied by 1.022 (92/90) for 2012 and $1.034(92 / 89)$ for 2013 when seasonality ratios involving milk volume were calculated.

The P2/P1 ratio of milk volume was calculated as the sum of the milk volume in $\mathrm{P} 2$ divided by the sum of the milk volume in $\mathrm{P} 1$. The $\mathrm{P} 2 / \mathrm{P} 1$ of SCC was calculated as the sum of the 3 BTSCC in P2 divided by the sum of the 3 BTSCC in $\mathrm{P} 1$. The $\mathrm{P} 2 / \mathrm{P} 1$ ratios were calculated for each farm and for each year. The P2/P1 ratios were motivated by the summer to winter ratio to describe seasonality in milk production and reproduction as a result of heat stress (Flamenbaum, 2012).

\section{Statistical Analysis}

Descriptive analyses were carried out with Microsoft Excel 2013 (Microsoft, Redmond, WA) and statistical analysis with SAS 9.3 (SAS Institute Inc., 2011). All analyses were done separately for 2012 and 2013. We used local nonparametric regression performed with SAS procedure LOESS with its defaults settings to help visualize patterns in the figures. To perform statistical comparisons of means we used the SAS procedure T-Test with log-transformed BTSCC observations because the BTSCC distribution was right skewed. The log-transformation resulted in approximately normally 
distributed observations. Correlation coefficients were calculated with SAS procedure Spearman, which is robust and nonparametric because we wanted to retain all observations in the data set. Significance was declared if $P<0.05$, and a trend was declared if 0.05 $\leq P<0.10$.

\section{RESULTS}

\section{Descriptive Statistics}

Table 1 shows that the ASCCy was 342,000 cells $/ \mathrm{mL}$ in 2012 and decreased $(P=0.009)$ to 327,000 cells $/ \mathrm{mL}$ in 2013. The WSCCy were 297,000 cells $/ \mathrm{mL}$ in 2012 and 274,000 cells $/ \mathrm{mL}$ in 2013 . The weighted averages were therefore 13 and 16\% lower than the arithmetic averages of SCC in the respective years. The means of WSCCf and WSCCm were lower in 2013 than in 2012. The mean monthly milk volume was $677,000 \mathrm{~kg}$, which is the milk of approximately 900 cows.

Figure 1 shows the distribution of the farms by their milk volume. In 2012, $77 \%$ of the farms shipped $\leq 9$ million $\mathrm{kg}$ of milk per year and were responsible for $32 \%$ of the total milk volume. In $2013,63 \%$ of the farms shipped $\leq 9$ million $\mathrm{kg}$ and were responsible for $26 \%$ of the total milk volume in that year.

Figure 2a shows a weak negative association between milk volume and ASCCf. The Spearman correlation coefficients were $-0.30(P=0.002)$ for 2012 and -0.33 $(P<0.001)$ in 2013 . In Figure $2 \mathrm{~b}$, the Spearman correlation coefficient were $-0.28(P=0.003)$ in 2012 and $-0.31(P=0.002)$ in 2013 , indicating a weak negative correlation between milk volume and BTSCC.

\section{Seasonality of Milk Volume, ASCCm, and WSCCm}

Figure 3 shows that clear seasonal patterns were observed for milk volume, ASCCm, and WSCCm. The greatest average milk volume was in March and the lowest average milk volume was in September for both years (68 and $73 \%$ of the volume in March, for 2012 and 2013). In 2012 and 2013, 99 and $96 \%$ of the farms showed a P2/P1 ratio of milk volume $<1$, respectively. Figure 3 also reveals that in every calendar month the

Table 1. Description of the monthly data on bulk tank SCC, milk volume, and calculated statistics from 2 Florida milk buyer cooperatives in 2012 and 2013

\begin{tabular}{|c|c|c|c|c|c|c|}
\hline Variable & $\mathrm{N}$ & Mean & Median & $\mathrm{SD}$ & Minimum & Maximum \\
\hline Milk volume ${ }^{1}\left(\times 10^{3} \mathrm{~kg}\right)$ & 1,308 & 677 & 501 & 702 & 2.3 & 4,742 \\
\hline $\mathrm{BTSCC}^{2}\left(\times 10^{3}\right.$ cells $\left./ \mathrm{mL}\right)$ & 1,308 & 342 & 326 & 135 & 76 & 1,097 \\
\hline $\mathrm{WSCCf}^{4}\left(\times 10^{3}\right.$ cells $\left./ \mathrm{mL}\right)$ & 109 & 336 & 327 & 110 & 127 & 806 \\
\hline $\mathrm{ASCCm}^{5}\left(\times 10^{3}\right.$ cells $\left./ \mathrm{mL}\right)$ & 12 & 341 & 319 & 39 & 290 & 408 \\
\hline $\mathrm{WSCCm}^{6}\left(\times 10^{3}\right.$ cells $\left./ \mathrm{mL}\right)$ & 12 & 299 & 290 & 27 & 262 & 343 \\
\hline $\operatorname{DIFm}^{9}\left(\times 10^{3}\right.$ cells $\left./ \mathrm{mL}\right)$ & 12 & -43 & -39 & 16 & -69 & -25 \\
\hline \multicolumn{7}{|l|}{2013} \\
\hline Milk volume $\left(\times 10^{3} \mathrm{~kg}\right)$ & 1,200 & 717 & 543 & 774 & 6.4 & 4,854 \\
\hline $\mathrm{BTSCC}\left(\times 10^{3}\right.$ cells $\left./ \mathrm{mL}\right)$ & 1,200 & 327 & 302 & 137 & 66 & 855 \\
\hline ASCCf $\left(\times 10^{3}\right.$ cells $\left./ \mathrm{mL}\right)$ & 100 & 327 & 329 & 108 & 131 & 660 \\
\hline WSCCf $\left(\times 10^{3}\right.$ cells $\left./ \mathrm{mL}\right)$ & 100 & 318 & 312 & 104 & 124 & 643 \\
\hline DIFm $\left(\times 10^{3}\right.$ cells $\left./ \mathrm{mL}\right)$ & 12 & -49 & -44 & 18 & -77 & -30 \\
\hline
\end{tabular}

\footnotetext{
${ }^{1}$ Volume of milk shipped per farm per calendar month.

${ }^{2}$ BTSCC $=$ bulk tank SCC per farm per calendar month.

${ }^{3} \mathrm{ASCCf}=$ average BTSCC per farm, not weighted by milk volume.

${ }^{4} \mathrm{WSCCf}=$ average BTSCC per farm, weighted by milk volume.

${ }^{5} \mathrm{ASCCm}=$ average BTSCC per calendar month, not weighted by milk volume.

${ }^{6} \mathrm{WSCCm}=$ average BTSCC per calendar month, weighted by milk volume.

${ }^{7} \mathrm{P} 2$ = August, September, October; P1 = February, March, April.

${ }^{8} \mathrm{DIFf}=\mathrm{WSCCf}-\mathrm{ASCCf}$.

${ }^{9} \mathrm{DIFm}=\mathrm{WSCCm}-\mathrm{ASCCm}$.
} 


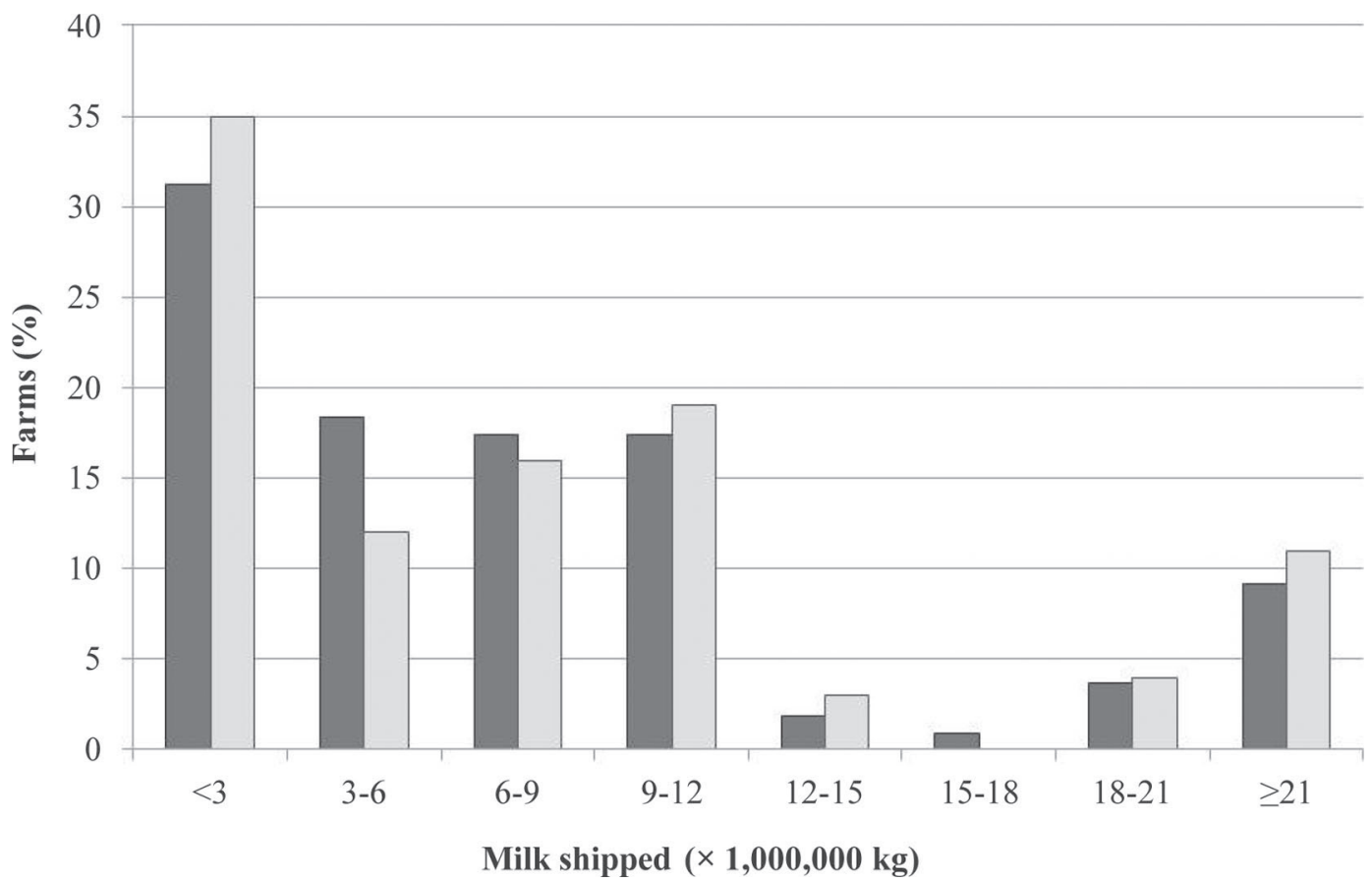

Figure 1. Distribution of Florida dairy farms based on their annual milk volume in 2012 (dark gray bar) and 2013 (light gray bar).

WSCCm was numerically lower than the ASCCm. Using the arithmetic averages of WSCCm for the 3 mo in P1 and P2, the increase in WSCCm was $19 \%$ in 2012 and $51 \%$ in 2013 in $\mathrm{P} 2$ compared with P1.

In both 2012 and 2013, the greatest differences between WSCCm and ASCCm were in September when WSCCm were 69,000 and 77,000 cells/mL lower than the ASCCm, respectively. The smallest difference was in January of both years when WSCCm were 25,000 and 30,000 cells/mL lower for 2012 and 2013, respectively.

\section{Seasonality of Distribution of Farms and Milk Volume by BTSCC Category}

Figure $4 \mathrm{a}$ shows the seasonality of the distribution of farms for the 5 BTSCC categories. In 2012, $85 \%$ of the total milk volume had a BTSCC $<400,000$ cells/ $\mathrm{mL}$, and $72 \%$ of the monthly shipments had a BTSCC $<400,000$ cells $/ \mathrm{mL}$. In $2013,86 \%$ of the total milk volume and $74 \%$ of the farms' monthly shipments had a BTSCC $<400,000$ cells $/ \mathrm{mL}$.

The largest changes in the percentage of farms occurred in the high BTSCC categories. In April 2012, $16 \%$ of the farms had BTSCC $\geq 400,000$ cells $/ \mathrm{mL}$, but in August 2012, $50 \%$ of the farms had a BTSCC equal or over this limit. In 2013, the same pattern was observed, but the changes were even larger. Eight percent of the farms had a BTSCC $\geq 400,000$ cells $/ \mathrm{mL}$ in April. This value increased to $57 \%$ in August.

Figure $4 \mathrm{~b}$ shows the seasonality of the distribution of milk volume for various BTSCC thresholds. Again, the biggest differences were in the high BTSCC categories. In April of 2012, only $7 \%$ of the milk volume had a BTSCC $\geq 400,000$ cells $/ \mathrm{mL}$. This amount increased to $31 \%$ in August. In 2013, the increase was from $3 \%$ of the milk volume in April to $37 \%$ of the milk volume in August with $\geq 400,000$ cells $/ \mathrm{mL}$.

\section{Differences Between WSCCf and ASCCf}

The descriptive statistics for DIFf and DIFm are shown in Figure 1. The association between annual milk volume and DIFf, calculated as WSCCf minus ASCCf, is shown in Figure 5a for each farm. Farms that shipped more milk during the year had a DIFf $\approx$ 0 , either indicating a constant milk volume throughout the year, a constant BTSCC, or both. However, DIFf was negative for 90 farms (83\%) in 2012 and 97 farms $(97 \%)$ in 2013. Consequently, a large portion of the farms had pooled milk with a lower SCC than their arithmetic averages suggested. The Spearman correlation coefficients between milk volume and DIFf were $0.32(P<0.001)$ and $0.43(P<0.001)$ in 2012 and 2013 , respectively. 
(a)

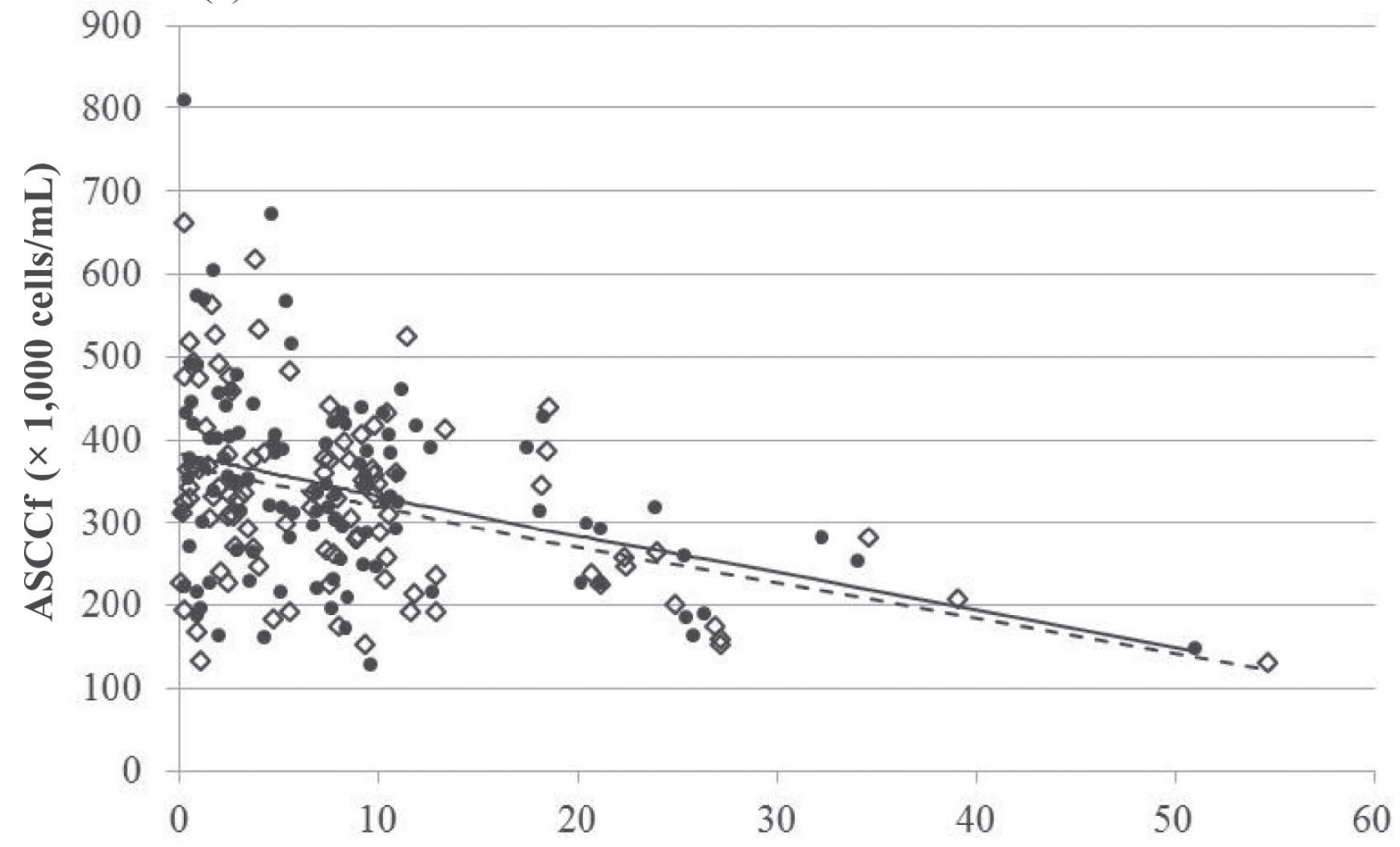

(b)

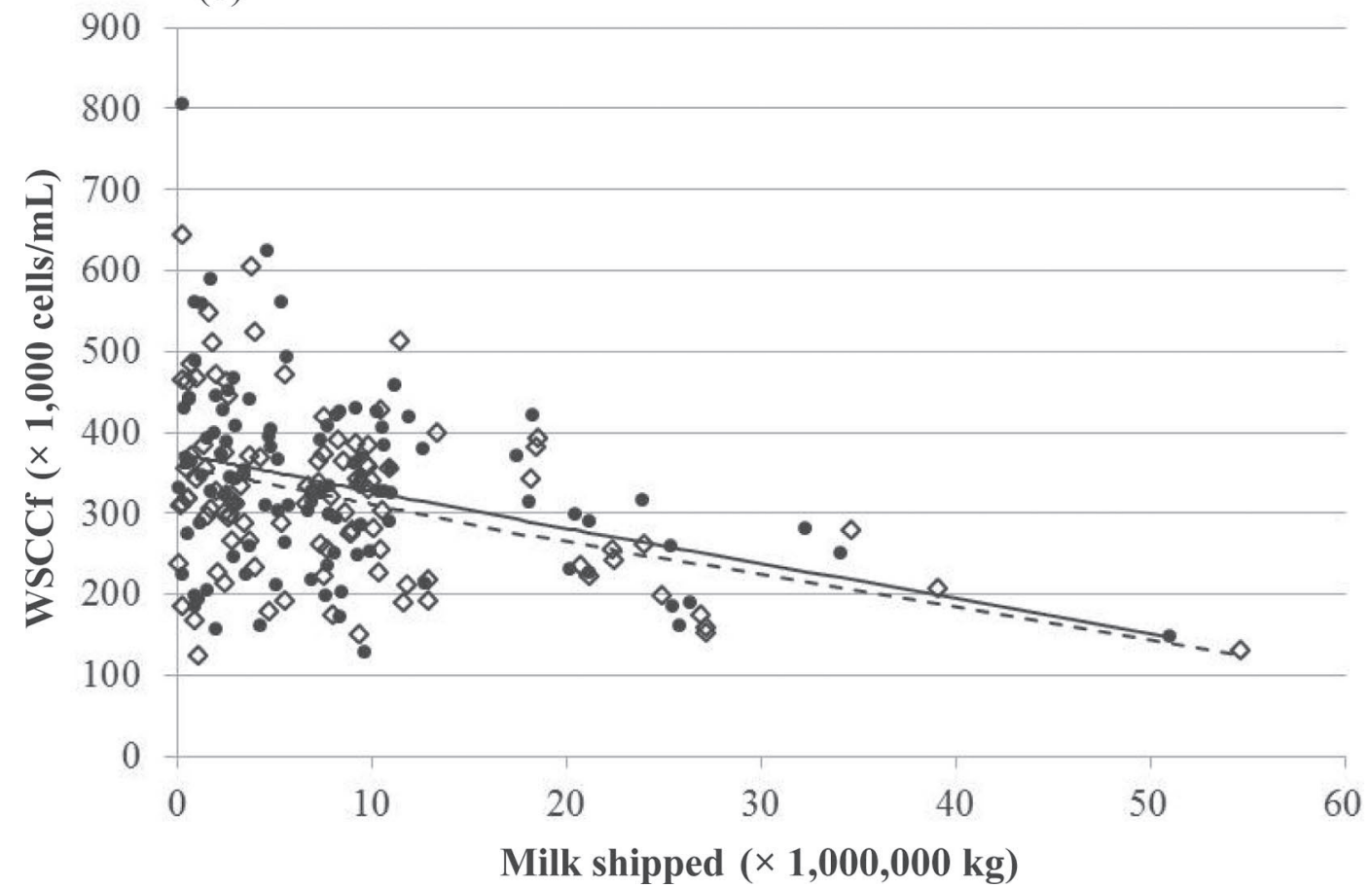

Figure 2. Association between annual milk volume, arithmetic average SCC (ASCCf), and weighted average SCC (WSCCf) in 2012 (a; $\mathrm{n}=$ 109) and $2013(\mathrm{~b} ; \mathrm{n}=100)$ by farm. $\bullet=2012$ data points; $\diamond=2013$ data points; the black line is the nonparametric regression line for 2012 ; the dashed line is the nonparametric regression line for 2013. 
(a)

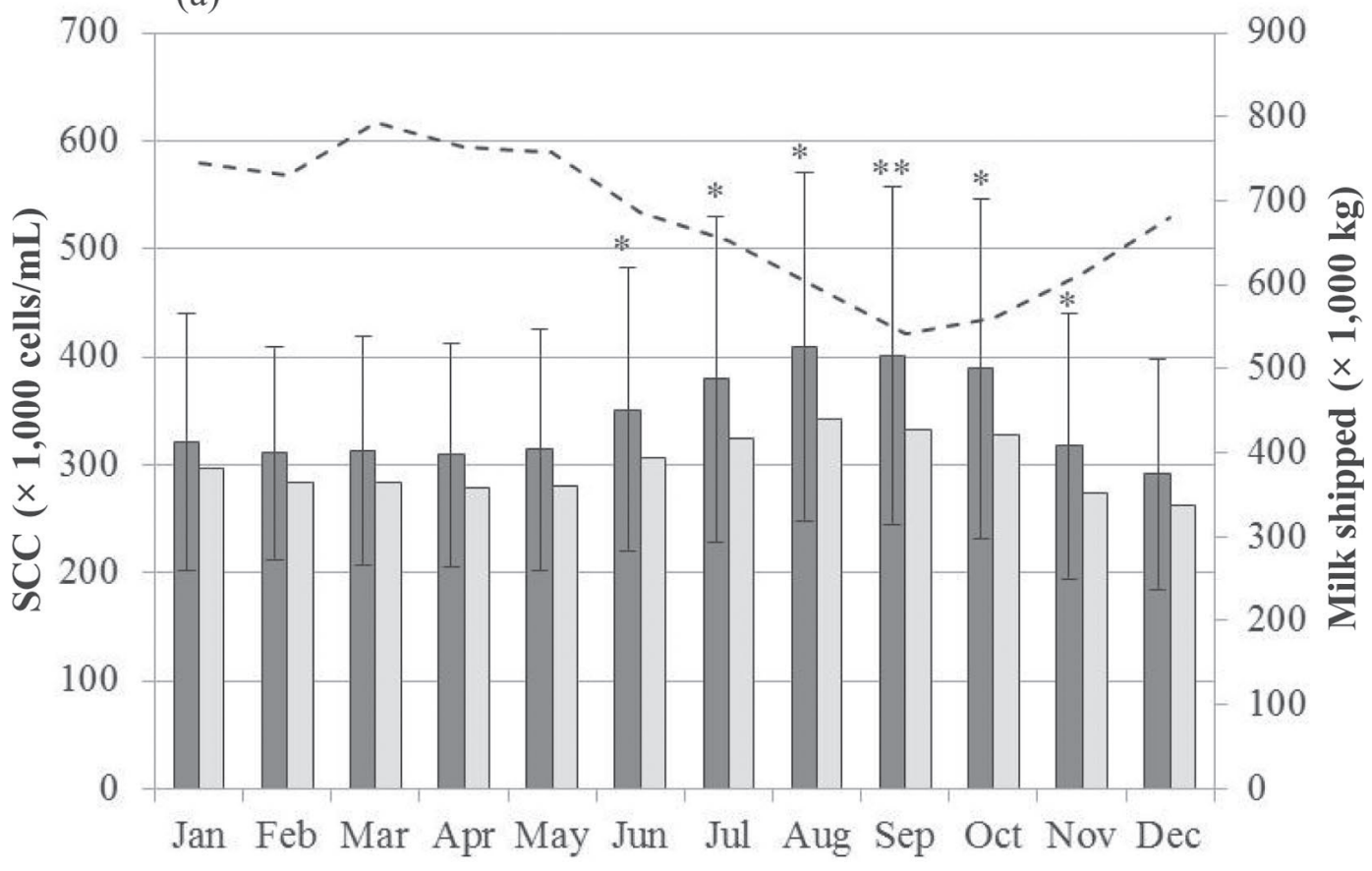

(b)

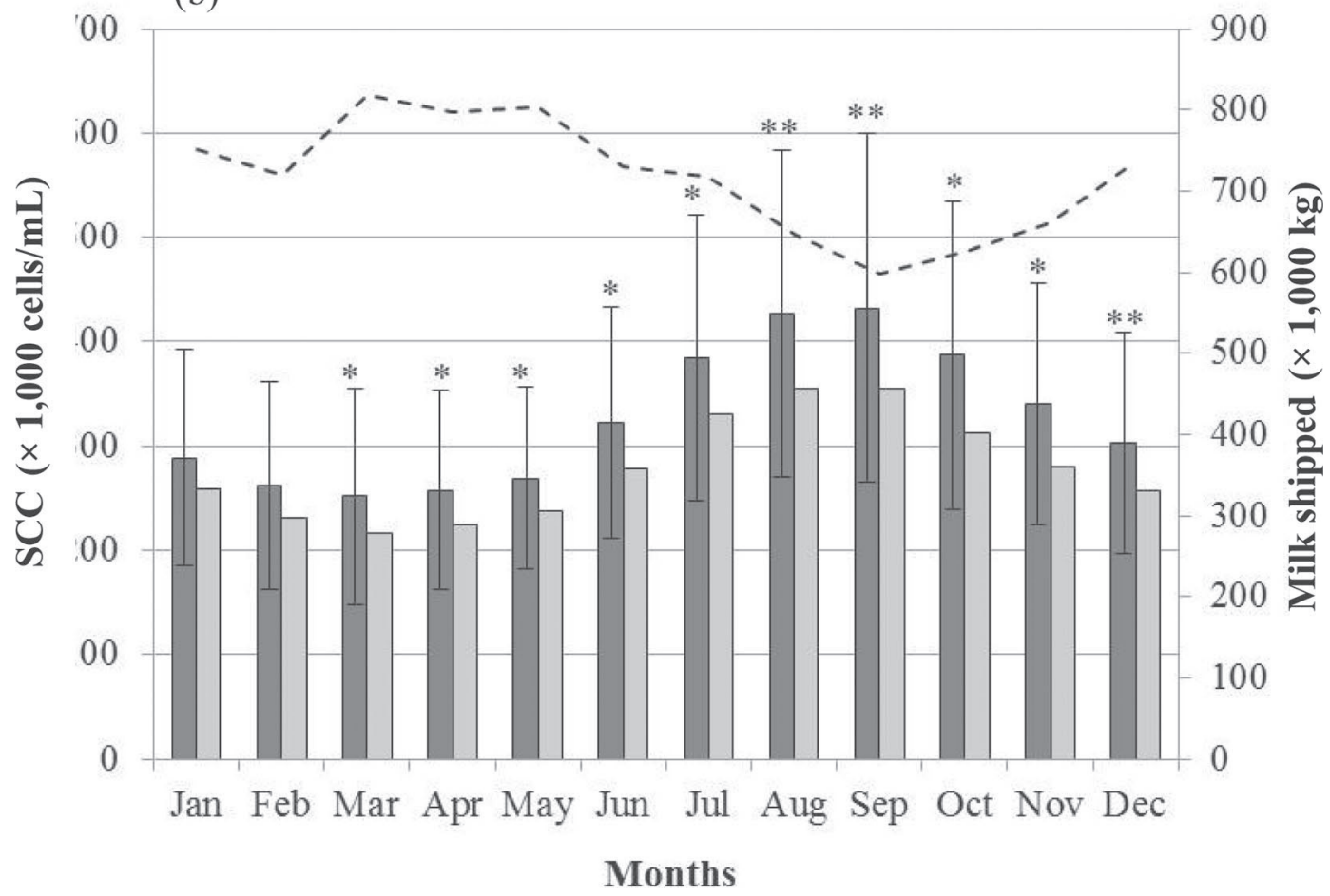

Figure 3. Average milk volume per farm, arithmetic average SCC (ASCCm), and weighted average SCC (WSCCm) in 2012 (a) and 2013 (b) per calendar month. The standard deviation for ASCCm is also shown. Differences between the WSCCm and ASCCm were tested with a $t$-test using log-transformed data. Dashed line indicates the volume of milk shipped; ASCCm is the dark gray bar; WSCCm is the light gray bar. ${ }^{*} P<0.05 ; * * P<0.01$ 
OUR INDUSTRY TODAY

$\square<200 \square 200-300 \quad \square 300-400 \quad$ 目 400-600 $\square \geq 600$

(a)

$\operatorname{BTSCC}(\times 1,000$ cells $/ \mathrm{mL})$

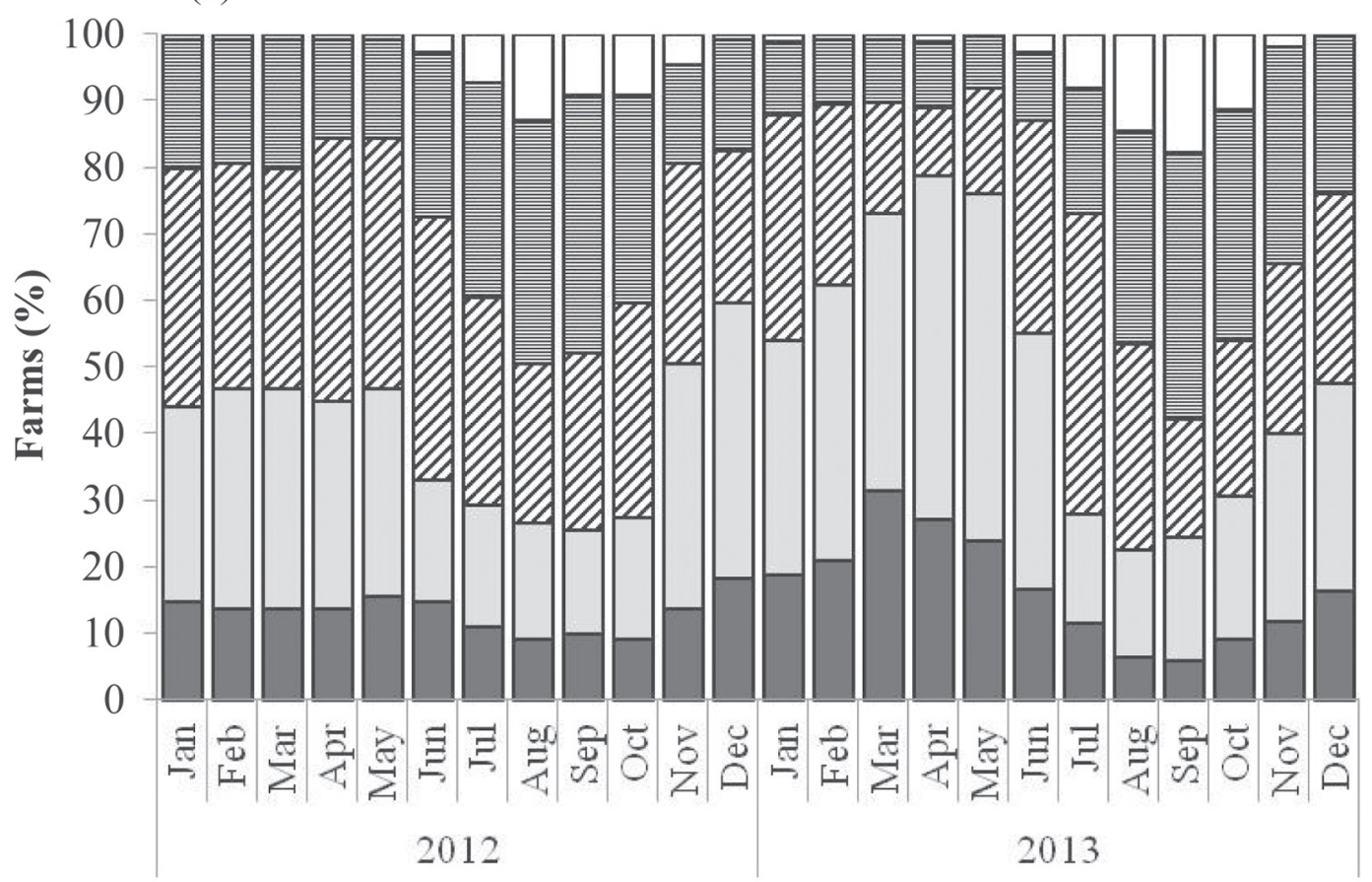

(b)

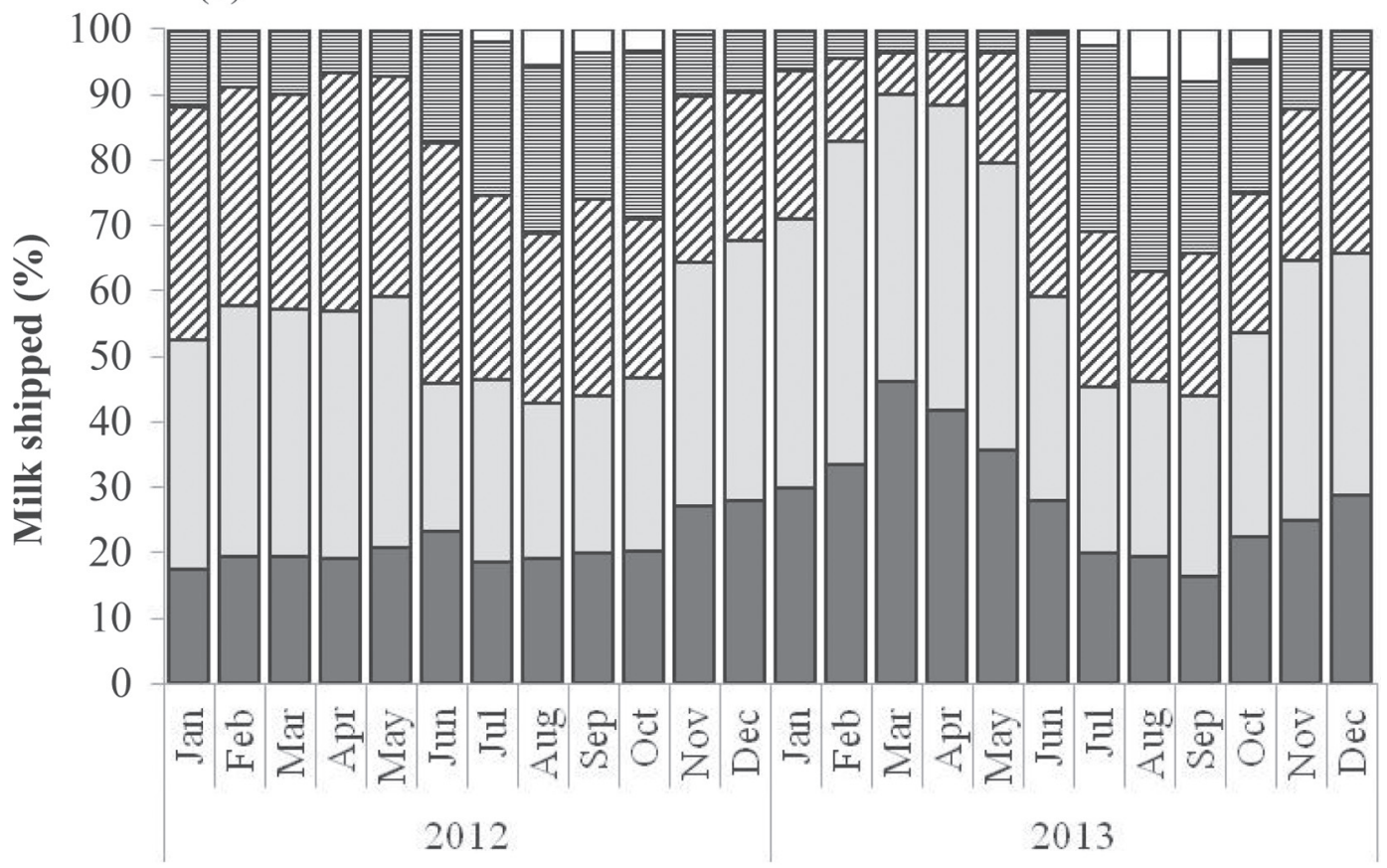

Month and year

Figure 4. Percentage of farms (a) and milk volume (b) for 5 bulk tank SCC thresholds and calendar months in 2012 and 2013. 
(a)

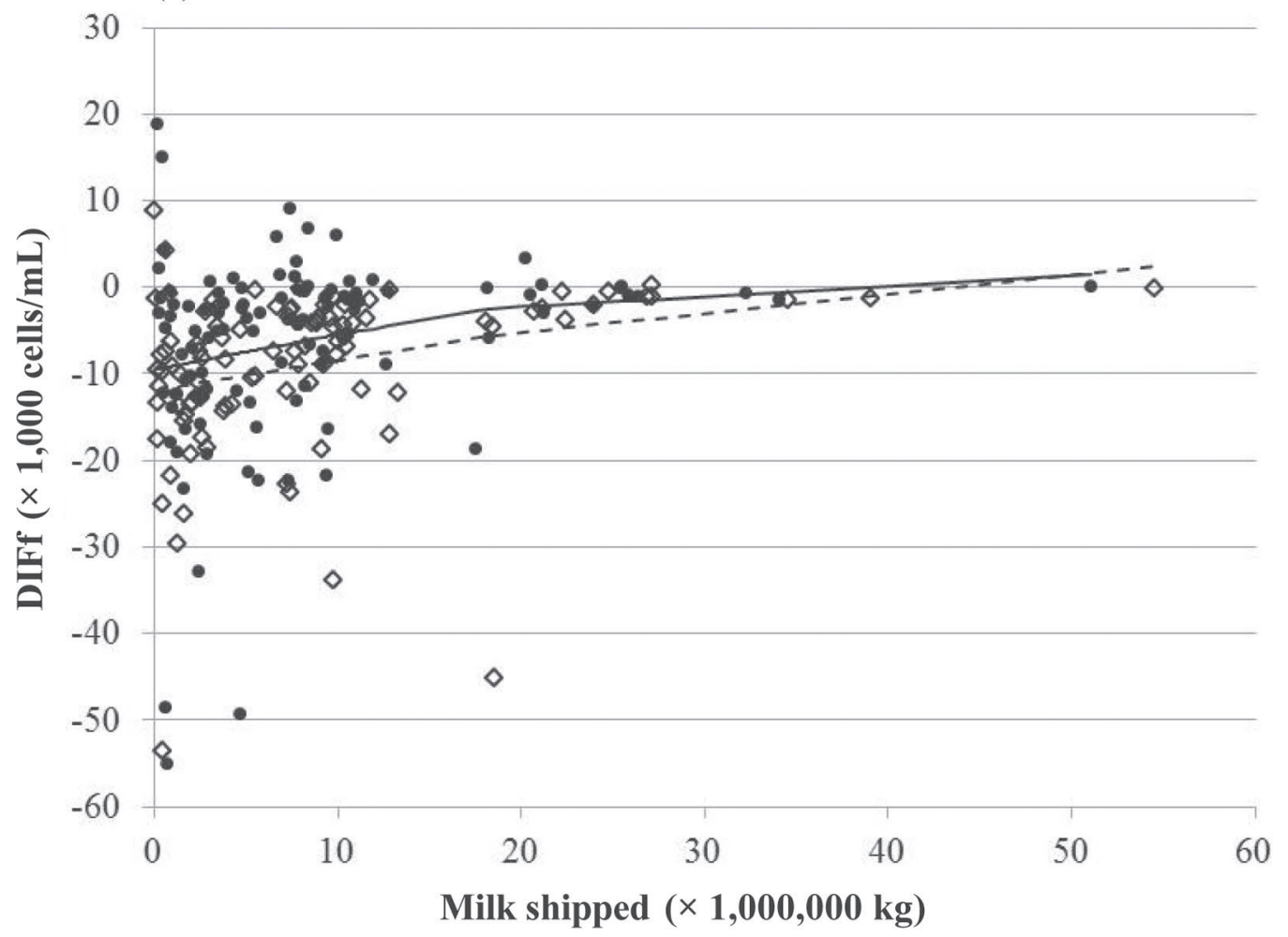

(b)

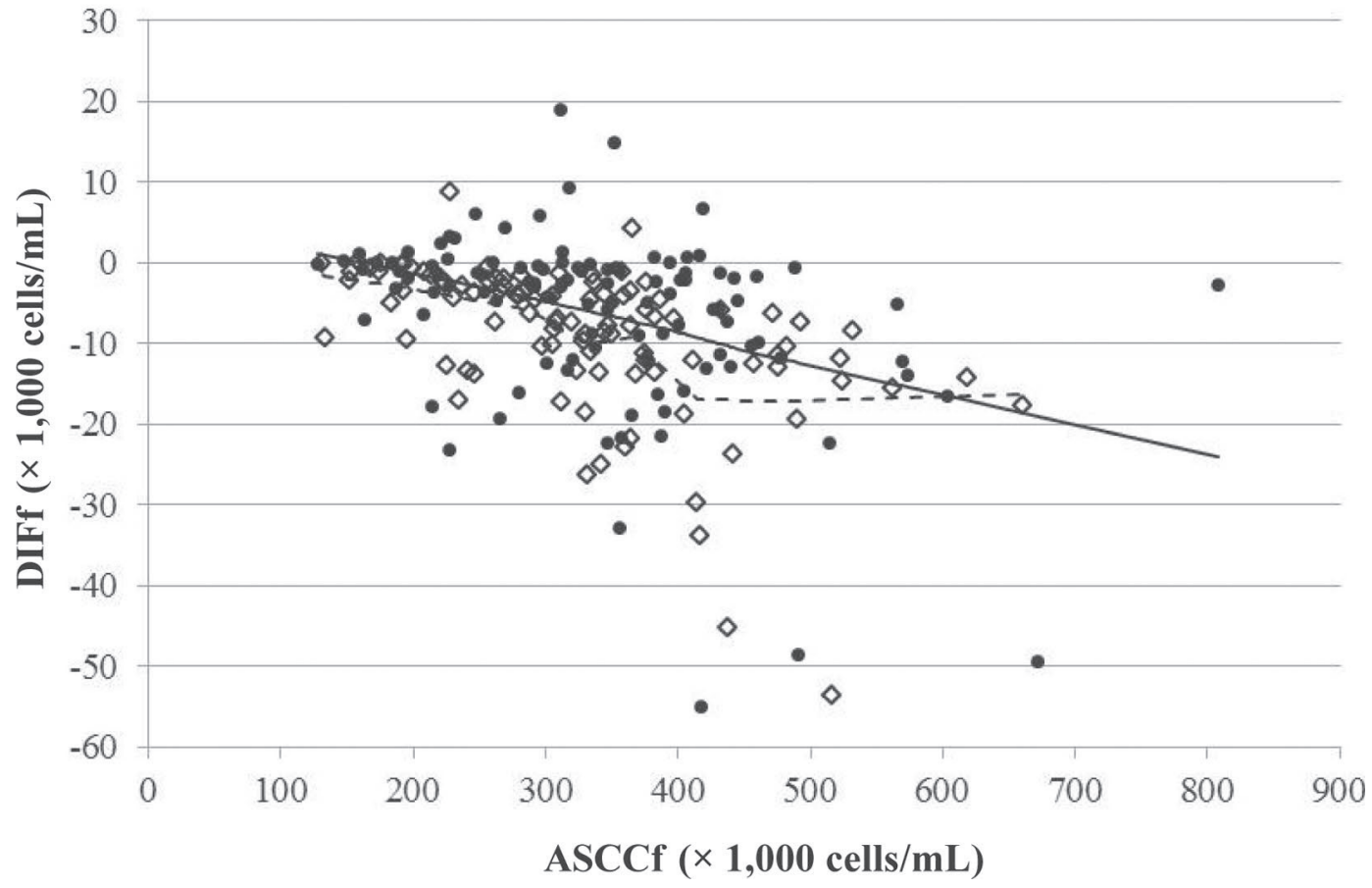

Figure 5. Association between annual milk volume (a) and arithmetic average SCC (ASCCf; b) on the difference between weighted average SCC per farm (WSCCf) and ASCCf per farm (DIFf = WSCCf - ASCCf). $\bullet=2012$ data points; $\diamond=2013$ data points; the black line is the nonparametric regression line for 2012; the dashed line is the nonparametric regression line for 2013. 
Figure 5b shows the association between ASCCf and DIFf. Farms with a higher ASCCf tended to have a greater DIFf. The Spearman correlation coefficients between ASCCf and DIFf were $-0.41(P<0.001)$ and $-0.61(P<0.001)$ in 2012 and 2013 , respectively.

In $2012,56 \%$ of the farms had a DIFf between 0 and $-9,999$ cells $/ \mathrm{mL}, 18 \%$ were between $-10,000$ and $-19,999$ cells $/ \mathrm{mL}$, and $8 \%$ were $\leq-20,000$ cells $/ \mathrm{mL}$. Only $17 \%$ of the farms had a DIFf $>0$. In 2013, the percentages of farms with a DIFf between 0 and $-9,999$, between $-10,000$ and $-19,999$, and $\leq-20,000$ cells $/ \mathrm{mL}$ were 61,27 , and $9 \%$, respectively. Only $3 \%$ of the farms had a DIFf $>0$ in 2013.

\section{Association Between Seasonality and Annual Milk Volume}

Farms that shipped more milk in a year tended to have less seasonality in their BTSCC and their milk volume throughout the year (Figure 6). In 2012, the mean for the P2/P1 ratio of SCC was 1.30 , which indicates a $30 \%$ higher SCC in P2 than in P1. In 2012, $83 \%$ of farms had a P2/P1 ratio of SCC $>1$. Fifty-seven percent of farms had a $\mathrm{P} 2 / \mathrm{P} 1$ ratio of SCC between 1.0 and $1.49,21 \%$ were between 1.5 and 1.99 , and $5 \%$ of farms had a P2/P1 ratio of SCC $\geq 2.0$ in 2012. In 2013, the mean for the P2/P1 ratio of SCC was 1.65. In 2013, $99 \%$ of the farms had a $\mathrm{P} 2 / \mathrm{P} 1$ ratio of $\mathrm{SCC}>1.0$. The percentages of farms were 37,47 , and $15 \%$ in the $\mathrm{P} 2 / \mathrm{P} 1$ ratio of SCC categories of between 1 and 1.49, 1.5, and 1.99 , and $\geq 2.0$, respectively. The Spearman correlation coefficients between the P2/P1 ratio of SCC and milk volume were $-0.20(P=0.037)$ and $-0.22(P=0.026)$ in 2012 and 2013, respectively.

For the P2/P1 ratio of milk volume, the averages were 0.68 and 0.74 in 2012 and 2013, respectively, which show 32 and $26 \%$ lower milk volume in P2 than in P1. For 2012 and 2013, 99 and $96 \%$ of the farms showed a $\mathrm{P} 2 / \mathrm{P} 1$ ratio of milk volume $<1$, respectively. In 2012, $37 \%$ of the farms had a $\mathrm{P} 2 / \mathrm{P} 1$ ratio of milk volume $>0.75,50 \%$ were between 0.50 and 0.75 , and $13 \%$ had a $\mathrm{P} 2 / \mathrm{P} 1$ ratio of milk volume $<0.50$. In 2013 , the percentages of farms in these 3 categories were 42,49 , and $5 \%$, respectively. The Spearman correlation coefficients between milk volume and $\mathrm{P} 2 / \mathrm{P} 1$ ratio of milk volume were $0.46(P<0.001)$ and $0.41(P<0.001)$ in 2012 and 2013 , respectively.

\section{Association Between Seasonality and the Difference Between WSCCf and ASCCf}

Figure 7 shows again that farms that were more seasonal in both their milk volume and SCC tended to have a bigger negative difference between WSCCf and ASCCf. The Spearman correlation coefficients between the P2/P1 ratio of SCC and DIFf were -0.80 $(P<0.001)$ and $-0.52(P<0.001)$ in 2012 and 2013, respectively (Figure 7a). The Spearman correlation coefficients between the $\mathrm{P} 2 / \mathrm{P} 1$ ratios of milk volume and DIFf were $0.51(P<0.001)$ and $0.84(P<0.001)$ in 2012 and 2013, respectively (Figure 7b).

Almost all farms were seasonal in both their milk volume and SCC (Figure 8). In our study, 89 farms in $2012(82 \%)$ and 95 farms in $2013(95 \%)$ had both a P2/ $\mathrm{P} 1$ ratio of milk volume $<1$ and a $\mathrm{P} 2 / \mathrm{P} 1$ ratio of $\mathrm{SCC}$ $>1$, respectively. The Spearman correlation coefficients between both $\mathrm{P} 2 / \mathrm{P} 1$ ratios were $-0.16(P=0.099)$ and $-0.22(P=0.031)$ in 2012 and 2013 , respectively.

\section{DISCUSSION}

The present study documented the associations of BTSCC from farms in Florida with time of the year and milk volume. USDA-NASS (2014) reported total milk volumes of 1,060 and 1,081 million $\mathrm{kg}$ for Florida in 2012 and 2013, whereas a total of 885 (83\%) and $861(80 \%)$ million $\mathrm{kg}$ were shipped by the farms in this study. Farms not included in the study were not members of the 2 milk buyer cooperatives that provided the data for this study, or had incomplete data in our data set. The average monthly milk volume indicated an average herd size of approximately 900 cows. Based on our knowledge of the Florida dairy industry, we believe that the characteristics of the Florida dairy farms not included in the data set are not markedly different from the farms included in the data set.

\section{SCC Averages}

The arithmetic annual average of all 1,308 monthly BTSCC records (Table 1) for 2012 in this study was 46,000 cells $/ \mathrm{mL}$ lower than the annual average reported by Pighetti et al. (2014). They reported monthly BTSCC records from all Florida farms whose data were obtained by the Florida Department of Agriculture and Consumer Services. Their data included all licensed dairy farms, but only a fraction of the SCC of the milk shipped in a month was reported to the state. Milk volume was not available in their data set. For 2013, G. M. Pighetti (University of Tennessee, Knoxville, personal communication) reported an average of 359,000 cells/mL for Florida, which is 32,000 cells $/ \mathrm{mL}$ higher than our ASCCy of 327,000 cells $/ \mathrm{mL}$. It is not clear what caused these differences. The WSCCy for 2012 and 2013 were 23 and $24 \%$ lower, respectively, than the average SCC reported for Florida by Pighetti. 

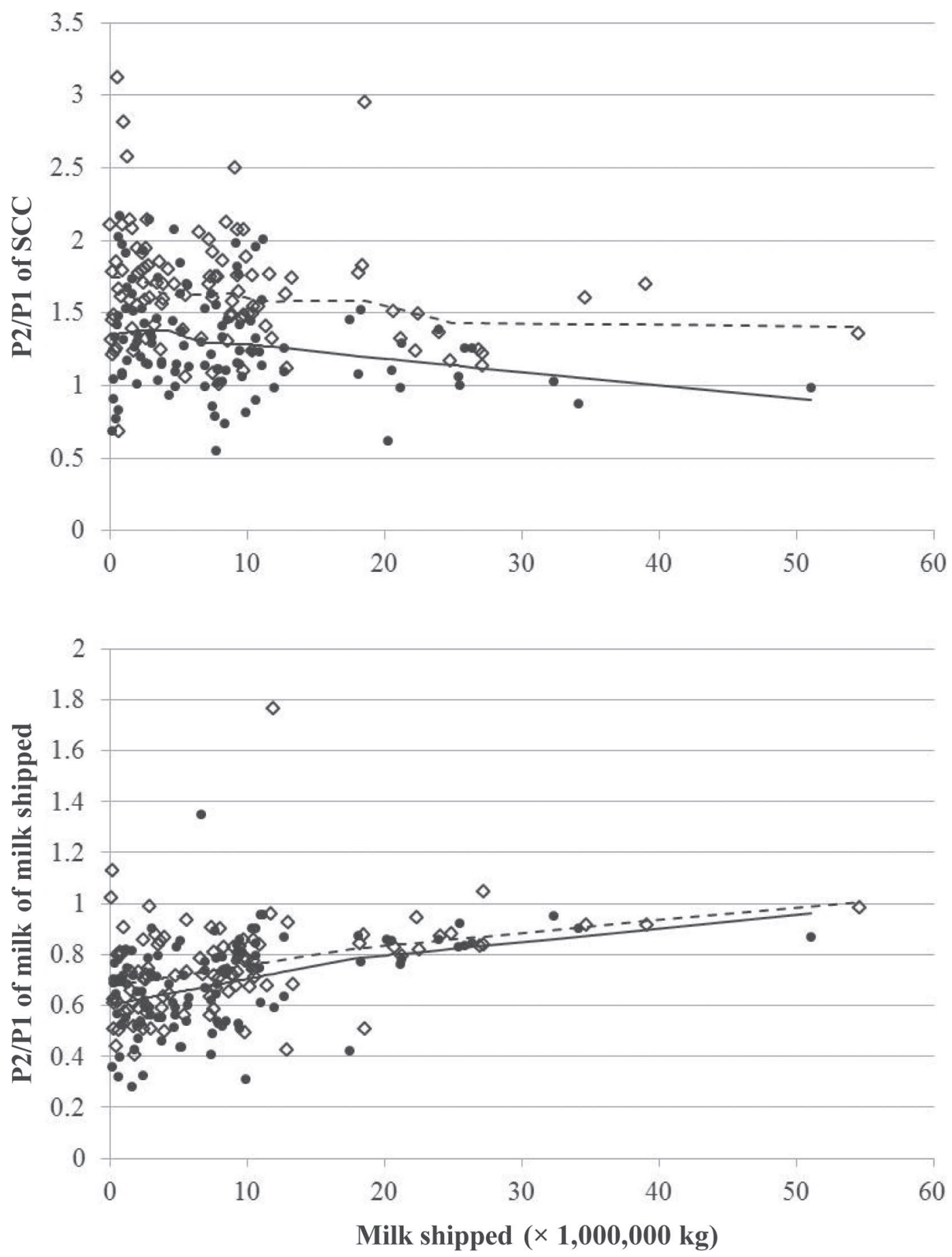

Figure 6. Association between annual volume of milk shipped and the P2/P1 ratios of SCC (a) and volume of milk shipped (b). P1 is February, March, and April; and P2 is August, September, and October. $\bullet=2012$ data points; $\diamond=2013$ data points; the black line is the nonparametric regression line for 2012; the dashed line is the nonparametric regression line for 2013.

The DHIA averages for SCC in Florida were 75,000 (22\%) and 98,000 (30\%) lower than the ASCCy for 2012 and 2013. The average SCC reported by DHIA is not weighted by herd milk volume. The lower average SCC for dairy farms enrolled in DHIA program may be due to their better mastitis control programs and more efficient management practices (Smith et al., 1995; Rodrigues et al., 2005) than the general population of farms. 

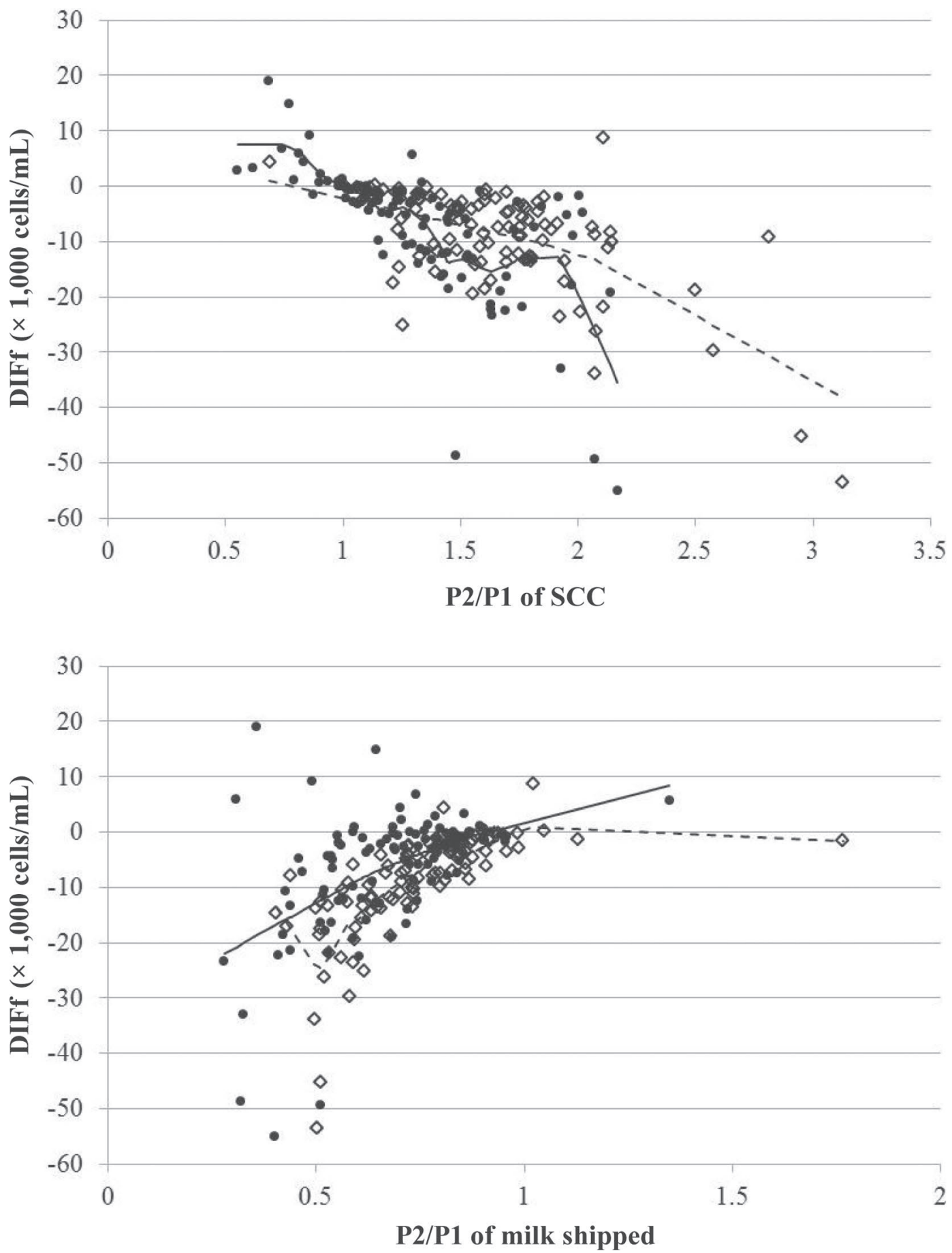

Figure 7. Association between the P2/P1 ratio of SCC (a) and the P2/P1 ratio of milk volume (b) and the difference (DIFf) between weighted average SCC per farm (WSCCf) and arithmetic average SCC (ASCCf; DIFf = WSCCf - ASCCf). P1 is February, March, and April; and P2 is August, September, and October. $\bullet=2012$ data points; $\diamond=2013$ data points; the black line is the nonparametric regression line for 2012; the dashed line is the nonparametric regression line for 2013.

The arithmetic average of the 12 monthly SCC reported for FO6 (293,000 cells/mL) for 2012 was 4,000 cells/mL lower than the WSCCy in this study. For 2013, FO6 reported an arithmetic average based on
12 monthly SCC of 264,000 cells $/ \mathrm{mL}$, which is 10,000 cells/mL lower than the WSCCy we observed. Annual results of our study and the FO6 data were therefore similar. 


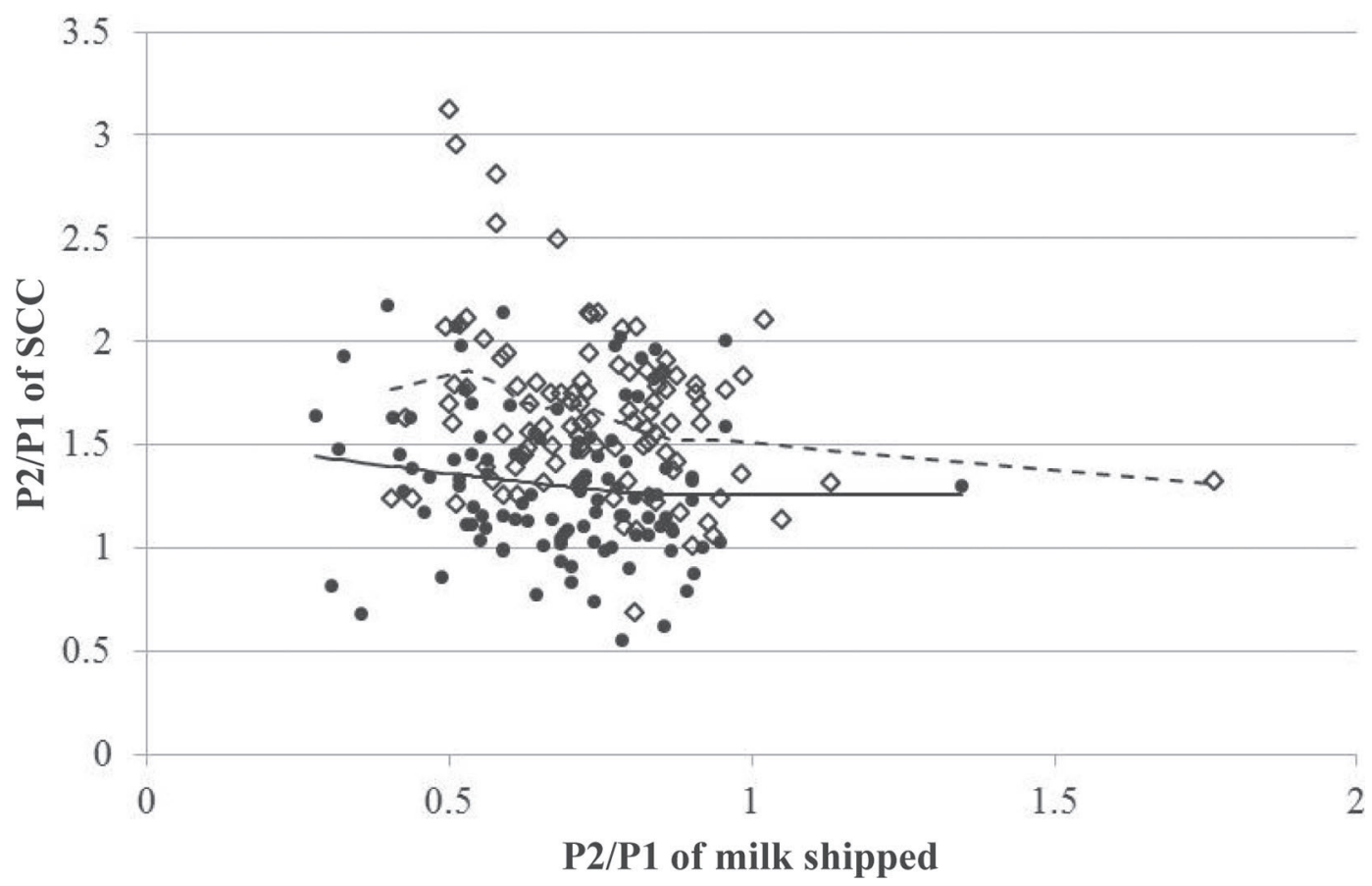

Figure 8. Association between the P2/P1 ratio of milk volume and the P2/P1 ratio of SCC in 2012 and 2013 . P1 is February, March, and April; and P2 is August, September, and October. Legend: • 2012 data points; $\diamond 2013$ data points; the black line is the nonparametric regression line for 2012; the dashed line is the nonparametric regression line for 2013.

\section{BTSCC Thresholds}

In our data set, $1 \%$ of all monthly records had a BTSCC $\geq 750,000$ cells $/ \mathrm{mL}$ and $27 \%$ had a BTSCC $\geq 400,000$ cells $/ \mathrm{mL}$. For 2013, DHIA reported that 2 and $12 \%$ of the herd test-day SCC in the United States, which often are determined once per month, were $>750,000$ and $>400,000$ cells $/ \mathrm{mL}$, respectively (Norman and Walton, 2014). In Florida, 2 and 12\% (2012) and 1 and $16 \%$ (2013) of the DHIA test-day SCC were $>750,000$ and $>400,000$ cells $/ \mathrm{mL}$, respectively (Norman and Walton, 2014).

In 2012, 99.9\% of the milk volume in 4 Federal Marketing Orders (Upper Midwest, Central, Mideast, and Southwest) had milk-weighted SCC $<750,000$ cells/ $\mathrm{mL}$, and $97 \%$ of the farms shipped milk with an SCC $<750,000$ cells $/ \mathrm{mL}$. When the limit of 400,000 cell $/ \mathrm{mL}$ was considered, $96 \%$ of the milk and $65 \%$ of all farms in the 4 orders shipped milk below this limit (USDAAPHIS, 2013). The USDA-APHIS data for 2013 were not available. Our results are similar to results for the 4 Federal Marketing Orders.

\section{Seasonality of BTSCC and Milk Volume}

In this study, most farms shipped less milk, but with a higher BTSCC, during P2 than during P1. The sub- tropical climate in Florida with its high temperature and high humidity in the summer is conducive to an increase in intrammamary infections and reduction in milk production (Smith et al., 2000; West, 2003). These effects of heat stress may explain part of the increase in BTSCC and decrease in milk volume a warmer period (Morse et al., 1988; Norman et al., 2013).

In addition, calving occurs more likely in the fall and winter in Florida (DeLorenzo et al., 1992; De Vries et al., 2005) so that during the warmer months relatively more cows are late in lactation. The decline in milk yield and milk constituents during late lactation might lead to higher SCC as a result of decreasing dilution (Clements et al., 2005; Cole et al., 2009; More et al. (2012). In our study, we could not distinguish between the effects of stage of lactation and direct effect of heat stress on the seasonality of SCC and milk volume because calving dates were not available.

The average seasonality in both BTSCC and milk volume was greater in 2013 than in 2012, as is shown by the average $\mathrm{P} 2 / \mathrm{P} 1$ ratio of $\mathrm{SCC}$ (1.65 versus 1.30$)$ and the average $\mathrm{P} 2 / \mathrm{P} 1$ ratio of milk volume ( 0.74 versus 0.68). Reasons for the increase in seasonality in 2013 are not clear, but the overall SCC was decreased in 2013. The correlation between the P2/P1 ratio of SCC and the $\mathrm{P} 2 / \mathrm{P} 1$ ratio of milk volume was weak, however. In 2012, 19 farms had both a P2/P1 ratio of milk vol- 
ume and a $\mathrm{P} 2 / \mathrm{P} 1$ ratio of $\mathrm{SCC}<1$ and in 2013 this was only 1 farm, indicating that during P1 both their milk volume and BTSCC were higher than in P2. Pighetti et al. (2014) documented a similar amount of seasonality in BTSCC data that was largely obtained from the same farms as in the current data set. The $\mathrm{P} 2 / \mathrm{P} 1$ ratios of SCC in the FO6 data were 1.12 and 1.43 for 2012 and 2013, respectively.

The seasonality in milk production and in SCC for Florida DHIA data (Norman et al., 2013) was lower than in our study. Using the same methodology, the $\mathrm{P} 2 / \mathrm{P} 1$ ratio of milk volume for the United States was 0.95 versus 0.68 in our study. The $\mathrm{P} 2 / \mathrm{P} 1$ ratio of $\mathrm{SCC}$ was 1.08 versus 1.65 in our study. Reasons for these differences are not clear.

In the Netherlands, Lievaart et al. (2007) observed an increase in the herd SCC during the summer months. We calculated a $\mathrm{P} 2 / \mathrm{P} 1$ ratio of SCC of approximately $1.25,1.3$, and 1.35 for farms in the categories of low, medium, and high SCC, respectively, from the data of Lievaart et al. (2007). These results are similar to our results for 2012 (1.3), but lower than our results for 2013 (1.65). Much more heat stress occurs in Florida than in the Netherlands, however. Working with seasonally calving herds in New Zealand, Clements et al. (2005) observed the lowest SCC in August, September, and November (N1), and the highest SCC in April, May, and June (N2). Their N2/N1 ratio of SCC was approximately 1.55. They further observed the highest milk production in September, October, and November (N3), and the lowest during March, April, and May (N4). The N4/N3 ratio of milk volume was approximately 0.55 . This seasonality is likely mostly attributed to stage of lactation effects.

Seasonality is a characteristic of a time series in which the data experience regular and predictable changes that recur every calendar year (http://www.investopedia.com/). We described seasonality as the ratio of the value in $3 \mathrm{mo}$ with generally the highest BTSCC divided by the value in 3 mo with a generally the lowest BTSCC. The quantification of seasonal effects has been expressed in the dairy literature in different ways, however. Green et al. (2006) calculated the difference between summer and winter, where summer was defined as May to September and winter as October to May. They also repeated their analysis with summer defined as July to September. Lievaart et al. (2007) used only the months with the highest and lowest SCC. Olde Riekerink et al. (2007) used the true astronomical seasons, but described the changes in SCC using the month with the highest and the lowest SCC. Flamenbaum (2012) quantified seasonality by defining a summer to winter ratio for variables such as conception rate and herd milk yield. Seasonality has also been described by a sine function applied to monthly milk production data (Weldon et al., 2003). The different definitions make comparisons of the amount of seasonality in dairy performance difficult.

\section{Milk Volume and BTSCC}

Farms that shipped lower milk volumes tended to have a higher BTSCC throughout the year and had greater seasonality in their BTSCC as well. They also had greater seasonality in the milk volume. In the present study, milk volume is a proxy for herd size, thereby indicating that larger herds tended to have lower BTSCC. Lower SCC was also documented in larger herds outside of Florida (Oleggini et al., 2001; Norman et al., 2011). In DHIA data (Norman et al., 2013; Norman and Walton, 2014), the average SCC in small herds (<50 cows) were 82,000 (2012) and 68,000 (2013) cells/mL higher than in large herds ( $>3,000$ cows).

In the United States, larger herds are more likely to establish and follow strict sanitation and mastitis control programs (Rodrigues et al., 2005). In the present study, larger farms tended to be less seasonal in their BTSCC and milk volume, indicating that they might provide more heat abatement. However, Barkema et al. (1999) reported that herds in the Netherlands with clean and accurate management styles (good record keepers, accurate in sampling cases of clinical mastitis, farmers knew the cows better and were used to checking the cow milk production every milking, enjoyed milking, were precise rather than fast, and had better overall hygiene) had fewer cows than those with quick and dirty practices. Those herds were much smaller than the typical herds in Florida, however. Archer et al. (2013) also reported that increasing herd sizes in England, Ireland, and Wales were associated with an increase in SCC at the cow level.

\section{Weighted SCC}

The weighted SCC in all Florida milk (WSCCy) were $13 \%$ (2012) and 16\% (2013) lower than the arithmetic annual averages calculated from the same monthly data ignoring milk volume (ASCCy). The lower weighted SCC is both the result of the observation that farms that shipped a greater volume of milk tended to have lower BTSCC, and second, the higher BTSCC during P2 were associated with a time of lower milk production on most farms. Consequently, the reported average SCC for a farm or group of farms should be weighted by milk volume if that average SCC is to represent the average annual milk quality. The effect of milk volume on the reported average SCC was the greatest in herds that were more seasonal in milk volume in our study. 
Therefore, the WSCCf in milk from those herds was much lower than their ASCCf.

The BTSCC was high in August, September, and October on many farms when a significant amount of milk was still produced, which may suggest that programs to improve milk quality should be focused on conditions during this period. Exceptions to the high BTSCC in P2 exist, with some farms in Florida showing remarkably low BTSCC throughout the year. Milk quality control efforts by these farms should be better understood and could be implemented on other farms to improve milk quality, especially during the warmer months.

\section{CONCLUSIONS}

The annual pooled SCC of all Florida milk was 13 to $16 \%$ lower than the arithmetic average of monthly BTSCC observations. This indicates a better overall quality of pooled milk from Florida than arithmetic averages suggest. Farms that shipped more milk during the year typically were less seasonal for both milk volume and BTSCC and had lower BTSCC. Almost all farms had a reduced milk volume and increased BTSCC during P2. Farms that were more seasonal in their milk volume generally were more seasonal in their BTSCC as well.

\section{ACKNOWLEDGMENTS}

The 2 participating milk buyer cooperatives are gratefully acknowledged for supplying the data for this study. Three anonymous reviewers helped to improve the article. This study was financially supported by USDA-NIFA AFRI grant award 2013-68004-20424 titled "Southeast Quality Milk Initiative: Controlling Mastitis and Improving Milk Quality."

\section{REFERENCES}

Allore, H. G., P. A. Oltenacu, and H. N. Erb. 1997. Effects of season, herd size, and geographic region on the composition and quality of milk in the Northeast. J. Dairy Sci. 80:3040-3049.

Archer, S. C., F. Mc Coy, W. Wapenaar, and M. J. Green. 2013. Association of season and herd size with somatic cell count for cows in Irish, English, and Welsh dairy herds. Vet. J. 196:515-521.

Atlanta Market Administrator. 2014. Estimated Market Average Component Tests and Somatic Cell Count for Producer Milk Jan. 2006 to Feb. 2014. Accessed Jul. 20, 2014. http://fmmatlanta. com/pdfstorage/Est_Components_FO6\&7.pdf.

Barbano, D. M., Y. Ma, and M. V. Santos. 2006. Influence of raw milk quality on fluid milk shelf life. J. Dairy Sci. 89(E. Suppl.):E15E19.

Barkema, H. W., J. D. van der Ploeg, Y. H. Schukken, T. J. G. M. Lam, G. Benedictus, and A. Brand. 1999. Management style and its association with bulk milk somatic cell count and incidence rate of clinical mastitis. J. Dairy Sci. 82:1655-1663.
Clements, A. C. A., D. U. Pfeiffer, and D. Hayes. 2005. Bayesian spatio-temporal modelling of national milk-recording data of seasonalcalving New Zealand dairy herds. Prev. Vet. Med. 71:183-196.

Cole, J. B., D. J. Null, and P. M. VanRaden. 2009. Best prediction of yields for long lactations. J. Dairy Sci. 92:1796-1810.

DeLorenzo, M. A., T. H. Spreen, G. R. Bryan, D. K. Beede, and J. A. M. van Arendonk. 1992. Optimizing model: insemination, replacement, seasonal production, and cash flow. J. Dairy Sci. 75:885-896.

De Vries, A., C. Steenholdt, and C. A. Risco. 2005. Pregnancy rates and milk production in natural service and artificially inseminated dairy herds in Florida and Georgia. J. Dairy Sci. 88:948-956.

FDA. 2009. Grade "A" Pasteurized Milk Ordinance, 2009 Revision. US Department of Health and Human Services. Washington, DC. Accessed Jul. 23, 2014. http://www.fda.gov/downloads/Food/ GuidanceRegulation/UCM209789.pdf.

Flamenbaum, I. 2012. Summer to Winter Ratio-A tool for evaluation of the effectiveness of farms' heat abatement treatments. DeLaval Milkproduction.com. Accessed May 20, 2014. http://www. milkproduction.com/Library/Scientific-articles/Housing/Summerto-Winter-Ratio---A-tool-for-evaluation-of-the-effectiveness-offarms-heat-abatement-treatments--/.

Green, M. J., A. J. Bradley, H. Newton, and W. J. Browne. 2006. Seasonal variation of bulk tank somatic cell counts in UK dairy herds: Investigations of the summer rise. Prev. Vet. Med. 74:293-308.

Hand, K. J., A. Godkin, and D. F. Kelton. 2012. Milk production and somatic cell counts: A cow-level analysis. J. Dairy Sci. 95:13581362

Harmon, R. J. 1994. Physiology of mastitis and factors affecting somatic cell counts. J. Dairy Sci. 77:2103-2112.

Lievaart, J. J., W. D. J. Kremer, and H. W. Barkema. 2007. Short communication: Comparison of bulk milk, yield-corrected, and average somatic cell counts as parameters to summarize the subclinical mastitis situation in a dairy herd. J. Dairy Sci. 90:4145-4148.

Ma, Y., C. Ryan, D. M. Barbano, D. M. Galton, M. A. Rudan, and K. J. Boor. 2000. Effects of somatic cell count on quality and shelf-life of pasteurized fluid milk. J. Dairy Sci. 83:264-274.

More, S. J. 2009. Global trends in milk quality: Implications for the Irish dairy industry. Ir. Vet. J. 62(Suppl. 4):S5-S14.

More, S. J., T. A. Clegg, P. J. Lynch, and L. O'Grady. 2013. The effect of somatic cell count data adjustment and interpretation, as outlined in European Union legislation, on herd eligibility to supply raw milk for processing dairy products. J. Dairy Sci. 96:3671-3681.

More, S. J., T. A. Clegg, and L. O'Grady. 2012. Insights into udder health and intramammary antibiotic usage on Irish dairy farms during 2003-2010. Ir. Vet. J. 65:7.

Morse, D., M. A. DeLorenzo, C. J. Wilcox, R. J. Collier, R. P. Natzke, and D. R. Bray. 1988. Climatic effects on occurrence of clinical mastitis. J. Dairy Sci. 71:848-853.

Norman, H. D., T. A. Cooper, and F. A. Ross Jr. 2013. Somatic Cell Counts of Milk from Dairy Herd Improvement Herds during 2012. USDA-AIPL Research Report SCC14 (2-13). Accessed Aug. 1, 2014. https://www.cdcb.us/publish/dhi/dhi13/sccrpt.htm.

Norman, H. D., J. E. Lombard, J. R. Wright, C. A. Kopral, J. M. Rodriguez, and R. H. Miller. 2011. Consequences of alternative standards for bulk tank somatic cell count of dairy herds in the United States. J. Dairy Sci. 94:6243-6256.

Norman, H. D., and L. M. Walton. 2014. Somatic Cell Counts of Milk from Dairy Herd Improvement Herds during 2013. CDCB Research Report SCC15 (2-14). Accessed Apr. 29, 2014. https:// www.cdcb.us/publish/dhi/current/sccx.html.

Olde Riekerink, R. G. M., H. W. Barkema, and H. Stryhn. 2007. The effect of season on somatic cell count and the incidence of clinical mastitis. J. Dairy Sci. 90:1704-1715.

Oleggini, G. H., L. O. Ely, and J. W. Smith. 2001. Effect of region and herd size on dairy herd performance parameters. J. Dairy Sci. 84:1044-1050.

Pighetti, G. M., S. P. Oliver, R. A. Almeida, P. D. Krawczel, J. M. Fly, S. M. Schexnayder, C. S. Petersson-Wolfe, J. M. Bewley, L. E. Garkovich, D. M. Amaral-Phillips, L. M. Arnold, S. C. Nickerson, 
S. Hill-Ward, and A. De Vries. 2014. Southeast Quality Milk Initiative: Milk quality in the Southeast USA. Pages 209-201 in Proc. Natl. Mastitis Coun. Annu. Mtg., Fort Worth, TX. Natl. Mastitis Counc. Inc., Madison, WI.

Rodrigues, A. C. O., D. Z. Caraviello, and P. L. Ruegg. 2005. Management of Wisconsin dairy herds enrolled in milk quality teams. J. Dairy Sci. 88:2660-2671.

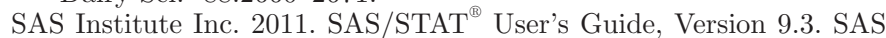
Inst. Inc., Cary, NC.

Schukken, Y. H., K. E. Leslie, A. J. Weersink, and S. W. Martin. 1992. Ontario bulk milk somatic cell count reduction program. 2. Dynamics of bulk milk somatic cell counts. J. Dairy Sci. 75:33593366.

Schukken, Y. H., D. J. Wilson, F. Welcome, L. Garrison-Tikofsky, and R. N. Gonzalez. 2003. Monitoring udder health and milk quality using somatic cell counts. Vet. Res. 34:579-596.

Smith, J. W., L. O. Ely, and M. Chapa. 2000. Effects of region, herd size, and milk production on reasons cows leave the herd. J. Dairy Sci. 83:2980-2987.

Smith, J. W., L. D. Guthrie, and L. O. Ely. 1995. Effect of herd size on management variables in Holstein herds. J. Dairy Sci. 98(Suppl. 1):318. (Abstr.)

Sordillo, L. M., K. Shafer-Weaver, and D. DeRosa. 1997. Immunobiology of the mammary gland. J. Dairy Sci. 80:1851-1865.
St-Pierre, N. R., B. Cobanov, and G. Schnitkey. 2003. Economic losses from heat stress by US livestock industries. J. Dairy Sci. 86(Suppl.):E52-E77.

USDA-AMS. 2011. Notice to the industry. Accessed Oct. 22, 2014 http://www.ams.usda.gov/AMSv1.0/getfile?dDocName=STELP RD3636640.

USDA-AMS. 2013. Florida fluid milk reports. Accessed May 28, 2014 http://www.fmmatlanta.com/pdfstorage/an6stat13.pdf.

USDA-APHIS. 2013. Determining U.S. milk quality using bulk-tank somatic cell counts, 2012. Accessed Jun. 17, 2014. http://www. aphis.usda.gov/animal_health/nahms/dairy/downloads/dairy_ monitoring/BTSCC_2012infosheet.pdf.

USDA-NASS. 2014. Milk Production Statistics (Florida). Accessed Jun. 18, 2014. http://future.aae.wisc.edu/data/monthly_values/ by_area $/ 99$ ?area $=$ Florida\&tab $=$ production\&grid $=$ true.

van Schaik, G., M. Lotem, and Y. H. Schukken. 2002. Trends in somatic cell counts, bacterial counts, and antibiotic residue violations in New York State during 1999-2000. J. Dairy Sci. 85:782-789.

Weldon, R. N., A. A. Washington, and R. L. Kilmer. 2003. Reducing seasonality in dairy production. Choices 18:35-38.

West, J. W. 2003. Effects of heat-stress on production in dairy cattle. J. Dairy Sci. 86:2131-2144. 